\title{
Multiple Criteria Method for Designing Distillation Sequence for Sharp Separation
}

\author{
A.G. Kamel ${ }^{1}$, M.Kaoud ${ }^{2}$ and S.M. Aly ${ }^{3}$ \\ ${ }^{1,2,3}$ Department of Chemical and Refining Engineering, Suez University, Egypt. \\ ORCID: 0000-0002-4320-3778 ( Kaoud)
}

\begin{abstract}
In almost every chemical process, distillation depending on sequences of separation. These systems of separation are utilized for preparation of feed, for the separation of products and finishing as well as for the waste treatment. This paper presents Multiple Criteria Approach for the synthesis of flow sheets with simple, sharp separator splitting. This approach based on quantification three heuristic rules will be used for selection of optimum separation sequence. The suggested procedure combines the values of the difference in normal boiling points of the components and the estimate separation mass load coefficients and relative volatility. The proposed method used to deal with previously reported literary problems produced optimal solutions which are better or at least similar to the optimum flow sheet with the indicated values, and overcame some obstacles of using the evolutionary, heuristic and mathematical programming. The proposed algorithm can be implement by hand calculation and characterized by its simplicity.
\end{abstract}

Keywords: Process synthesis; sharp separation; multiple criteria separation.

\section{INTRODUCTION}

One of the most important subjects in process synthesis has been the synthesis of optimum sequences of separation. Separation processes represent a significant portion of the operating expenses and the chemical plant's total capital investment, and a great deal of interest has been generated in developing systematic approaches that will select optimum sequences of separation much interest has been developed in developing systematic approaches that will select optimum sequences of separation. In the chemical unit design of sharp separation sequence is consider one of the most examined problems.

For the synthesis of sharp separation sequence Several of published works that have dealt with the synthesis, the main papers are reviewed in this area in Hendry et al.[1],Hlavacked [2],Westerberg [3],Stephanopolous [4],Nishida et al. [5],Umeda[6],Westerberger [7] and Floquet et al [8]. These authors proposed the following method, for resolving sharp separator sequence synthesis which could be categorizes into (3) key categories:-

Algorithmic methods attempt to solve and optimize the problem through the use of algorithms developed in the field of discrete mathematical programming, the major procedures used in the literature are the following:-

1- Dynamic programming (Hendry and Hughes [9].

2- Branch and bound type method (Westerberg and Stephanopoulos [10]; Rodrigo and seader [11].

3- Mixed integer linear programming methods (Andrecovich and Westerberg [12]; Floquet et al [13]

Evolutionary strategies attempt to identify the better scheme of separation by a sequence of evolutionary enhancements. The evolutionary approach depends on both the initial flow sheet and the evolutionary strategies, which can be categorizes into (2) key categories Heuristic strategy (Nath and Motard [14];Lu and Motard [15];Breadth first or depth first strategies (Stephanopoulos and Westerberg [16]; seader and Westerberg [17] Heuristic methods user rules of thumb resulting from long experience (Heaven [18];Powers [19];Nishimura et Hiraizumi[20]; Thompson and king [21];rudd et al. [22];NiIda et al.[23]; Dougls [ 24]. In this paper a synthesis approach suggested for sharp separation sequences combining the quantification three rules, difference in normal boiling point of components and relative volatility and the values of estimate separation mass load coefficient in multiple criteria decision method The effectiveness of this synthesis approach is illustrated using two problems.

\section{PROBLEM STATEMENT}

In the synthesis of chemical units. The design of sharp separation sequences is consider one of the most studied problems it could be stating as follows:

In the context a single multicomponent feed mixture with known conditions (i.e. flow rate, composition, pressure and temperature) synthesize a process which can separate the wanted products from the feed at minimum annual cost (including the sum of the plant's annual operating costs and investment costs). 
International Journal of Engineering Research and Technology. ISSN 0974-3154, Volume 13, Number 9 (2020), pp. 2305-2312

(C) International Research Publication House. https://dx.doi.org/10.37624/IJERT/13.9.2020.2305-2312

\section{SOLUTION METHOD}

The suggested methods for resolving synthesis of sharp separator sequence can be categorizes into (3) key categories:

Evolutionary strategies, heuristic methods and Algorithmic methods

The procedure described below is in the heuristic range and allows flow sheet structures to be easily found which are also nearly ideal solutions.

\subsection{Quantification of the Rules}

The synthesis algorithm is based on the application of expert rules, well suited for economical design problem .From an extensive complication of three rules of thumb have been retained :

I. If the difference $\Delta \mathrm{Tb}$ of the normal boiling point temperatures between two adjacent key components is big then split between these two components.

II. Favor the separation at the point where the relative volatility $\alpha \mathrm{i}, \mathrm{j}$ of two adjacent key components is the most important.

III. When the value of the estimated mass load (EML) coefficient of the spilt is small, perform this spilt.

\section{Rule 1:}

$$
\mu^{1}=\left\{\begin{array}{l}
0 \\
\frac{\Delta \mathrm{T}_{\mathrm{b}}-\mathrm{T}_{\min }}{\mathrm{T}_{\max }-\mathrm{T}_{\min }} \\
1
\end{array}\right.
$$

With $\mathrm{T}_{\min } \min \left(\Delta \mathrm{T}_{\mathrm{b}}\right)$ and $\left.\mathrm{T}_{\max }=\sum_{\mathrm{j}=1}^{\mathrm{n}-1} \quad \Delta \mathrm{Tb} / \mathrm{n}-1\right)$

Rule 2:

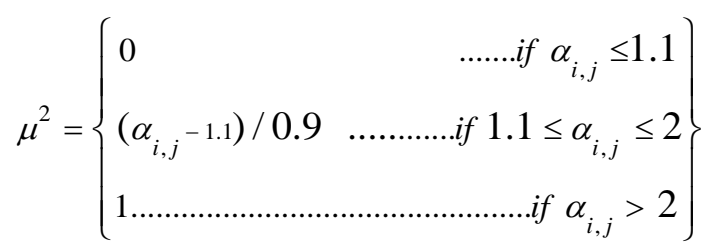

\section{Rule 3 :}

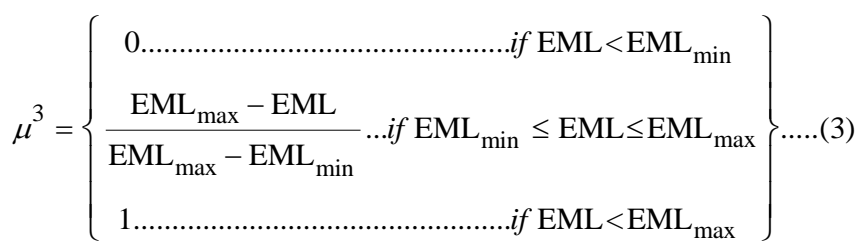

Estimated Mass Load (EML) coefficients definition and calculation The (EML) coefficients define as The molar flow rate which all separation units have to process downstream of the current separator before isolation of all the products required (Lu and Motard [25].

Without make reference to the physical properties of the components, the numerical value of (EML) coefficients is the weighted likelihood of every possible downstream sequence. In the following table (where xi is the molar fraction of the component $\mathrm{I}$ in the mixture), the main results are listed:

Table 1. Summary of the result of EML for N component

\begin{tabular}{|l|l|}
\hline $\begin{array}{l}\text { Number } \\
\text { component }\end{array}$ & EML Coefficients \\
\hline 1 & $\mathrm{O}$ \\
\hline 2 & $\mathrm{X}_{\mathbf{A}}+\mathrm{X}_{\mathbf{B}}=1$ \\
\hline 3 & $3 / 2 \mathrm{X}_{\mathbf{A}}+2 \mathrm{X}_{\mathbf{B}}+3 / 2 \mathrm{X}_{\mathbf{C}}$ \\
\hline 4 & $11 / 6 \mathrm{X}_{\mathbf{A}}+\mathrm{S} / 2 \mathrm{X}_{\mathbf{B}}+5 / 2 \mathrm{X}_{\mathbf{C}}+11 / 6 \mathrm{X}_{\mathbf{D}}$ \\
\hline 5 & $25 / 12 \mathrm{X}_{\mathbf{A}}+17 / 6 \mathrm{X}_{\mathbf{B}}+3 \mathrm{X}_{\mathbf{C}}+17 / 6 \mathrm{X}_{\mathbf{D}}+25 / 12 \mathrm{X}_{\mathbf{E}}$ \\
\hline & $\sum_{i=1}^{n} a_{n, i} W i t h \quad a_{1,1}=0$ \\
& $a_{1, i}=\sum_{k=1}^{i-1} \frac{1}{k} i f \quad i>1$ \\
& $a_{1, i}=\sum_{k=1}^{i-1} \frac{1}{k} i f+a_{1, i} \quad i>1$ \\
\hline
\end{tabular}

The value of EML coefficient for a spilt is bounded; Table 2 showing these two boundaries for some splits.

$\mathrm{EML}_{\min } \leq \mathrm{EML} \leq \mathrm{EML}_{\max }$.

Table 2: Bounds on Estimated Mass Load (EML) coefficients for $\mathrm{N}=5$ components

\begin{tabular}{|l|l|l|l|}
\hline Splits & EML & $\begin{array}{l}\text { EML } \\
\text { min }\end{array}$ & $\begin{array}{l}\text { EML } \\
\text { max }\end{array}$ \\
\hline $\mathrm{A} / \mathrm{BCDE}$ & $\mathrm{O}+11 / 6 \mathrm{X}_{\mathrm{B}}+5 / 2 \mathrm{X}_{\mathrm{C}}+5 / 2 \mathrm{X}_{\mathrm{D}}+11 / 6 \mathrm{X}_{\mathrm{E}}$ & 0 & $5 / 2$ \\
\hline $\mathrm{AB} / \mathrm{CDE}$ & $\mathrm{X}_{\mathrm{A}}+\mathrm{X}_{\mathrm{B}}+3 / 2 \mathrm{X}_{\mathrm{C}}+2 \mathrm{X}_{\mathrm{D}}+3 / 2 \mathrm{X}_{\mathrm{E}}$ & 1 & 2 \\
\hline $\mathrm{ADC} / \mathrm{DE}$ & $3 / 2 \mathrm{X}_{\mathrm{A}}+2 \mathrm{X}_{\mathrm{B}}+3 / 2 \mathrm{X}_{\mathrm{C}}+\mathrm{X}_{\mathrm{D}}+\mathrm{X}_{\mathrm{E}}$ & 1 & 2 \\
\hline $\mathrm{ABCD} / \mathrm{E}$ & $11 / 6 \mathrm{X}_{\mathrm{A}}+5 / 2 \mathrm{X}_{\mathrm{B}}+5 / \mathrm{X}_{\mathrm{C}}+11 / 6 \mathrm{X}_{\mathrm{D}}+0$ & 0 & $5 / 2$ \\
\hline $\begin{array}{l}\mathrm{A} / \mathrm{BCD} \text { or } \\
\mathrm{B} / \mathrm{CDE}\end{array}$ & $\mathrm{O}+3 / 2 \mathrm{X}_{\mathrm{B}}+2 \mathrm{X}_{\mathrm{C}}+3 / 2 \mathrm{X}_{\mathrm{D}}$ & 0 & 2 \\
\hline $\begin{array}{l}\mathrm{AB} / \mathrm{CD} \text { or } \\
\mathrm{BC} / \mathrm{DE}\end{array}$ & $\mathrm{X}_{\mathrm{A}}+\mathrm{X}_{\mathrm{B}}+\mathrm{X}_{\mathrm{C}}+\mathrm{X}_{\mathrm{D}}$ & 1 & 1 \\
\hline $\begin{array}{l}\mathrm{ABC} / \mathrm{D} \text { or } \\
\mathrm{BCD} / \mathrm{E}\end{array}$ & $3 / 2 \mathrm{X}_{\mathrm{A}}+2 \mathrm{X}_{\mathrm{B}}+3 / 2 \mathrm{X}_{\mathrm{C}}+\mathrm{O}$ & 0 & 2 \\
\hline $\mathrm{A} / \mathrm{BC}$ & $\mathrm{O}+\mathrm{X}_{\mathrm{B}}+\mathrm{X}_{\mathrm{C}}$ & 0 & 1 \\
\hline $\mathrm{AB} / \mathrm{C}$ & $\mathrm{X}_{\mathrm{A}}+\mathrm{X}_{\mathrm{B}}+\mathrm{O}$ & 0 & 0 \\
\hline $\begin{array}{l}\mathrm{A} / \mathrm{B} \text { or } \mathrm{B} / \mathrm{C} \\
\text { or C/D or } \\
\mathrm{D} / \mathrm{E}\end{array}$ & $\mathrm{O}$ & & 1 \\
\hline
\end{tabular}




\subsection{Multiple criteria decision method}

The multikcriteria problem in its general form for a finite set A of $n$ alternatives and certain system of $m$ assessment criteria $\mathrm{f}_{\mathrm{j}}$, can be defined as following: (Diakoulaki, et.al. (26)

$$
\operatorname{Max}\left\{f_{1}(\mathrm{a}), f_{2}(\mathrm{a}), \ldots \ldots \ldots f_{m}(\mathrm{a}) / \mathrm{a} \in \mathrm{A}\right\}
$$

We can define the membership function $\mathrm{x}_{\mathrm{j}}$ For each criterion $f_{\mathrm{j}}$ of this multicriteria problem by layout the values of $f_{j}$ to the interval $[0,1]$. This conversion is based on the ideal of the perfect point. Thus, the value $\mathrm{x}_{\mathrm{aj}}$ below, expresses the degree to whichever the substitute is near to the ideal value $f^{*}$ j .whichever is the better performance in criterion $j$, and far from the anti-ideal value $f_{\mathrm{j}^{*}}$, which is the worse performance in criterion $j$ both $f^{*}$ and $f_{\mathrm{j}^{*}}$, are actualized by at the least one of the substitutes under consideration.

$$
\mathrm{x}_{\mathrm{aj}}=\left[f_{\mathrm{j}}(\mathrm{a})-f_{\mathrm{j}^{*}}\right] /\left[f^{*} \mathrm{j}_{\mathrm{j}}-\mathrm{f}_{\mathrm{j}^{*}}\right]
$$

In this way the initial evaluation matrix is transformed into a matrix of relative scores with generic dimension $x_{i j}$. By examine the $\mathrm{jth}$ criterion in isolation, we generate a vector $\mathrm{x}_{\mathrm{j}}$ showing the scores of all $\mathrm{n}$ substitutes considered.

$$
\mathrm{x}_{j}=\left(\mathrm{x}_{j}(1), \mathrm{x}_{j}(2), \ldots, \mathrm{x}_{j}(\mathrm{n})\right)
$$

The standard deviation $\sigma \mathrm{j}$, which determines the contrast intensity of the corresponding criterion, is used for characterized each vector $x_{j}$. The standard deviation of $x_{j}$ is also an indicator of its importance for decision-making. Instead of use of standard deviation it is apparent that any other of the divergency in scores could be used

$$
\sigma \mathrm{x}=\sqrt{\frac{\sum_{\mathrm{i}=1}^{\mathrm{n}}\left(\mathrm{x}_{\mathrm{i}}-\overline{\mathrm{x}}\right)^{2}}{\mathrm{n}-1}}
$$

Where $\overline{\mathrm{x}}$ the mean variable of $\mathrm{x}$ and $\mathrm{n}$ is number of variable

The linear correlation coefficient $R_{I K}$ between $x_{i}$ and $x_{k}$ is calculated

$$
\mathrm{R}_{\mathrm{IK}}=\frac{\mathrm{n} \sum \mathrm{x}_{\mathrm{i}} \mathrm{x}_{\mathrm{k}}-\sum \mathrm{x}_{\mathrm{i}} \sum \mathrm{x}_{\mathrm{k}}}{\sqrt{\left(\mathrm{n} \sum \mathrm{x}_{\mathrm{i}}^{2}-\left(\sum \mathrm{x}_{\mathrm{i}}\right)^{2} \cdot\left(\mathrm{n} \sum \mathrm{x}_{\mathrm{k}}^{2}-\left(\sum \mathrm{x}_{\mathrm{k}}\right)^{2}\right)\right)}}
$$

The amount of $\mathrm{C}_{j}$ information emitted by the $j$ th criterion can beidentified

by composing measures that quantify the two notions by

means of the following formula of multiplicative aggregation:-

$$
\mathrm{C}_{\mathrm{j}}=\sigma_{\mathrm{j}} \cdot \sum_{\mathrm{k}=1}^{\mathrm{m}}(1-\mathrm{rjk})
$$

As per to the former analysis the higher the $C_{j}$ value, the greater the amount of information given by the corresponding criterion and its relative relevance to the decision-making process is increased. Objective weights result from the normalization of those values to the unit in accordance with the equation below.

$$
\mathrm{W}_{\mathrm{j}}=\mathrm{C}_{\mathrm{j}} / \sum_{\mathrm{k}=1}^{\mathrm{m}} \mathrm{C}_{\mathrm{k}}
$$

Construct a multi - criteria ranking of the firms examined according to the following aggregation formula:

$$
D_{i}=\sum_{j=1}^{m} W_{j} \cdot x_{i j}
$$

Where:

$\mathrm{D}_{\mathrm{i}}=$ the multicriteria score of firm $\mathrm{i}$,

$X_{\mathrm{ij}}=$ the score of firm $\mathrm{i}$ under criterion $\mathrm{j}$,

$\mathrm{w}_{j}=$ the weight criterion $j$

The strategy suggested is based on an assessment of the validity of each rule for every possible split. After the quantification step, the values of $\mu 1, \mu 2$ and $\mu 3$ for each spilt I are calculated and then multiple criteria decision method are applied.

Summarized of The key steps in the strategy showing in the following Fig.1

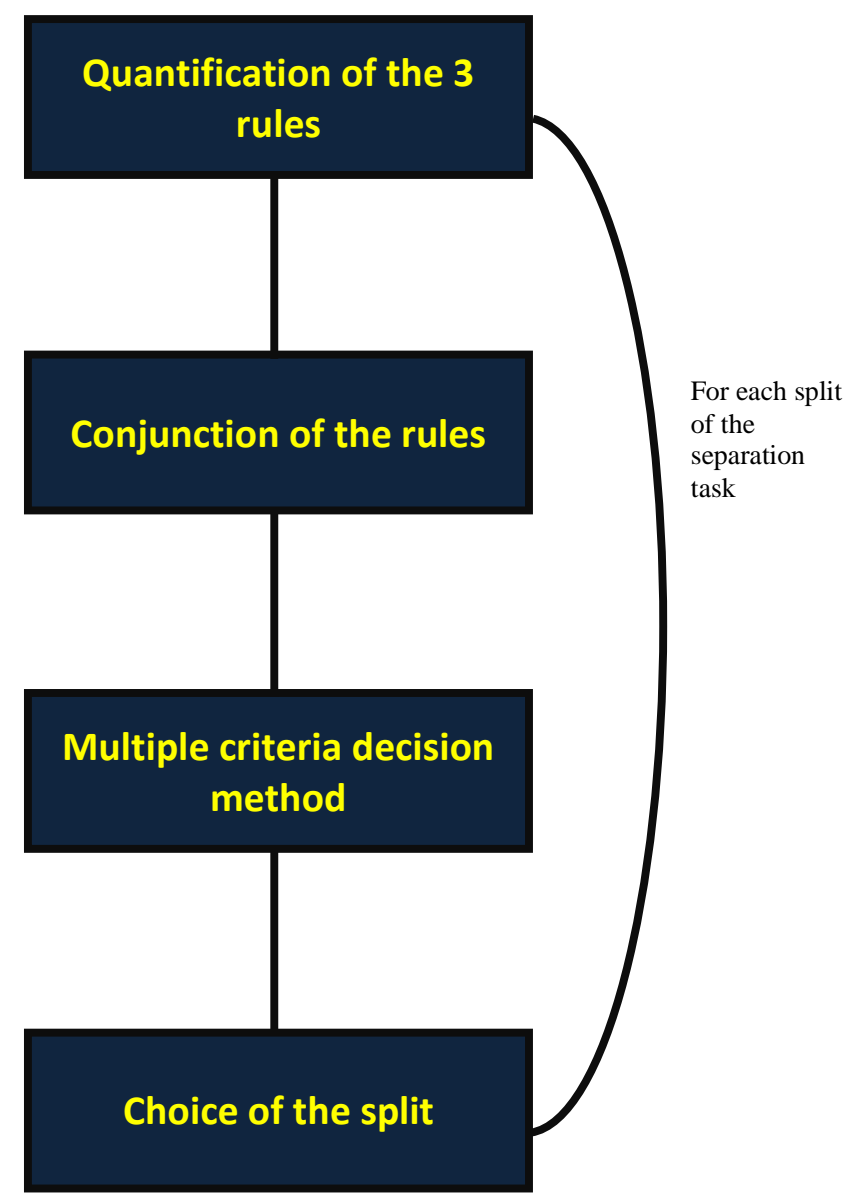

Fig.1 Main steps of the strategy 
International Journal of Engineering Research and Technology. ISSN 0974-3154, Volume 13, Number 9 (2020), pp. 2305-2312

(C) International Research Publication House. https://dx.doi.org/10.37624/IJERT/13.9.2020.2305-2312

\section{CASES STUDY}

Example 1: Separation of a 4 component mixture

Consider the separation of the mixture of four light hydrocarbons into pure components by ordinary distillation Floudas And Anastasiadis [27] Studied this case the problem specification are given in Table 1

Table 3. Data of The problem specification

\begin{tabular}{|c|c|c|c|c|}
\hline Component & Mole fraction & $\begin{array}{c}\text { Boling point } \\
\text { temperature }(\mathrm{k})\end{array}$ & $\begin{array}{c}\text { Normal boiling point } \\
\text { difference }(\mathrm{k})\end{array}$ & $\begin{array}{c}\text { Relative Volatility } \\
(\alpha)\end{array}$ \\
\hline A:1-Butane & 0.158 & 261.3 & & 11.4 \\
\hline B:N-Butane & 0.263 & & & 1.33 \\
\hline & & 272.7 & 28.3 & 2.40 \\
\hline C:I-Pentane & 0.210 & 300.8 & & 1.52 \\
\hline & & & 8.20 & \\
\hline D:N-Pentane & 0.369 & 309 & & \\
\hline
\end{tabular}

The first step is to determine the boiling point difference and normalized and hence the corresponding estimated mass load values for every split by using equation 1,2 and 3 Summarized of the calculations is showing in

Table 4. Summary of result by quantification of rules

\begin{tabular}{|c|c|c|c|c|c|c|}
\hline Split & $\begin{array}{c}\text { Boiling point } \\
\text { Difference } \\
\left(\Delta \mathrm{T}_{\mathrm{B}}\right)\end{array}$ & $\begin{array}{c}\text { Relative volatility } \\
(\alpha)\end{array}$ & $\begin{array}{c}\text { Estimated mass } \\
\text { load } \\
(\mathrm{EML})\end{array}$ & $\begin{array}{c}\text { Normalize boiling } \\
\text { point difference } \\
\left(\mu_{\mathbf{1}}\right)\end{array}$ & $\begin{array}{c}\text { Normalize relative } \\
\text { volatility } \\
\left(\mu_{\mathbf{2}}\right)\end{array}$ & $\begin{array}{c}\text { Normalize } \\
\text { Estimated mass } \\
\text { load } \\
\left(\mu_{\mathbf{3}}\right)\end{array}$ \\
\hline $\mathrm{A} / \mathrm{BCD}$ & 11.4 & 1.33 & 1.368 & 0.159 & 0 & 0.316 \\
\hline $\mathrm{AB} / \mathrm{CD}$ & 28.3 & 2.4 & 1 & 1 & 1 & 1 \\
\hline $\mathrm{ABC} / \mathrm{D}$ & 8.2 & 1.52 & 1.078 & 0 & 0.178 & 0.461 \\
\hline
\end{tabular}

In the second step calculate the standard deviation for each parameter by using equation (7) is summary of the calculations is shown in table 3

Table 5. Summary of result for standard deviation

\begin{tabular}{|c|c|c|c|c|}
\hline & $\mathrm{A} / \mathrm{BCD}$ & $\mathrm{AB} / \mathrm{CD}$ & $\mathrm{ABC} / \mathrm{D}$ & $\begin{array}{c}\text { Standard deviation } \\
(\sigma)\end{array}$ \\
\hline $\begin{array}{c}\text { Normalize boiling point difference } \\
\left(\mu_{\mathbf{1}}\right)\end{array}$ & 0.159 & 1 & 0 & 0.53764 \\
\hline $\begin{array}{c}\text { Normalize relative volatility } \\
\left(\mu_{2}\right)\end{array}$ & 0 & 1 & 0.178 & 0.5334 \\
\hline $\begin{array}{c}\text { Normalize Estimated mass load } \\
\left(\mu_{3}\right)\end{array}$ & 0.316 & 1 & 0.461 & 0.360417 \\
\hline
\end{tabular}

Then calculate the correlation $R_{i k}$ between each two normalization variables by using equation (8). The values of $R_{i k}$ are as follows: $R_{12}=0.95, R_{13}=0.939$ and $R_{23}=0.999$

Applying equation (9) to get the quantity of information $\mathrm{C}_{j}$ emitted by the $\mathrm{j}_{\mathrm{th}}$ criterion

Table 6. Summary of the results for standard deviation and $C_{j}$

\begin{tabular}{|c|c|c|}
\hline spilt & $\begin{array}{c}\text { Standard deviation } \\
(\sigma)\end{array}$ & $\mathrm{C}_{\mathrm{j}}$ \\
\hline $\mathrm{A} / \mathrm{BCD}$ & 0.53764 & 0.059395 \\
\hline $\mathrm{AB} / \mathrm{CD}$ & 0.5334 & 0.026755 \\
\hline $\mathrm{ABC} / \mathrm{D}$ & 0.36041 & 0.022197 \\
\hline
\end{tabular}


International Journal of Engineering Research and Technology. ISSN 0974-3154, Volume 13, Number 9 (2020), pp. 2305-2312

(C) International Research Publication House. https://dx.doi.org/10.37624/IJERT/13.9.2020.2305-2312

Applying equation (10) to obtain the object weight of each variable. The result as the following W1 $=0.548317$, W2 $=0.246866$ and $\mathrm{W} 3=0.204817$

For obtaining decision - maker, D, (or the multicriteria-score of firm), the following table is constructed:

Table 7. Evaluation of decision maker

\begin{tabular}{|c|c|c|c|c|c|}
\hline Solution & W1. $\mu 1$ & W2. $\mu 2$ & W3. $\mu 3$ & $\begin{array}{c}\text { multi-criteria-score } \\
\text { (D) }\end{array}$ & Ranking of firm \\
\hline $\mathrm{A} / \mathrm{BCD}$ & 0.087182 & 0 & 0.064722 & 0.151904 & 2 \\
\hline $\mathrm{AB} / \mathrm{CD}$ & 0.548317 & 0.246866 & 0.204817 & $\mathbf{1}$ & $\mathbf{1}$ \\
\hline $\mathrm{ABC} / \mathrm{D}$ & 0 & 0.043942 & 0.09442 & 0.138363 & 3 \\
\hline
\end{tabular}

By comparing the values of multicriteria-score (D) for all the possible split, split $A B / C D$ is chosen for it yield the highest $D$ value that is 1 .

The resulting sequence is $\mathbf{A B} / \mathbf{C D}, \mathbf{A} / \mathbf{B}$ and $\mathbf{C} / \mathbf{D}$

The cost of all possible towers is calculated by shortcut method and is shown in the following table 8

Table 8

\begin{tabular}{|l|l|l|l|}
\hline Column & Cost*10 $\left.10^{5} / \mathrm{yr}.\right)$ & Column & Cost $^{*} 10^{5}(\$ / \mathrm{yr})$. \\
\hline $\mathrm{A} / \mathrm{BCD}$ & 7.200 & $\mathrm{C} / \mathrm{D}$ & 6.922 \\
\hline $\mathrm{AB} / \mathrm{CD}$ & 5.869 & $\mathrm{~B} / \mathrm{C}$ & 2.099 \\
\hline $\mathrm{ABC} / \mathrm{D}$ & 10.801 & $\mathrm{~A} / \mathrm{B}$ & 3.345 \\
\hline $\mathrm{B} / \mathrm{CD}$ & 4.670 & $\mathrm{~A} / \mathrm{BC}$ & 6.400 \\
\hline $\mathrm{BC} / \mathrm{D}$ & 9.728 & $\mathrm{AB} / \mathrm{C}$ & 3.778 \\
\hline
\end{tabular}

The total cost of the possible separation sequences schemes as shown in table is calculated by shortcut method, and it was found that the optimum sequence is consistent with the results of proposed method.

Table 9. The total cost of possible separation sequences schemes.

\begin{tabular}{|l|l|l|}
\hline NO. & Separation & Cost*10 $(\$ /$ yr. $)$ \\
\hline 1 & AB/CD $, \mathrm{A} / \mathrm{B}, \mathrm{C} / \mathrm{D}$ & 1.548 \\
\hline 2 & $\mathrm{ABC} / \mathrm{D}, \mathrm{AB} / \mathrm{C}, \mathrm{A} / \mathrm{B}$ & 1.792 \\
\hline 3 & $\mathrm{~A} / \mathrm{BCD}, \mathrm{B} / \mathrm{CD}, \mathrm{C} / \mathrm{D}$ & 1.879 \\
\hline 4 & $\mathrm{~A} / \mathrm{BCD}, \mathrm{BC} / \mathrm{D}, \mathrm{B} / \mathrm{C}$ & 1.903 \\
\hline 5 & $\mathrm{ABC} / \mathrm{D}, \mathrm{A} / \mathrm{BC}, \mathrm{B} / \mathrm{C}$ & 1.931 \\
\hline
\end{tabular}

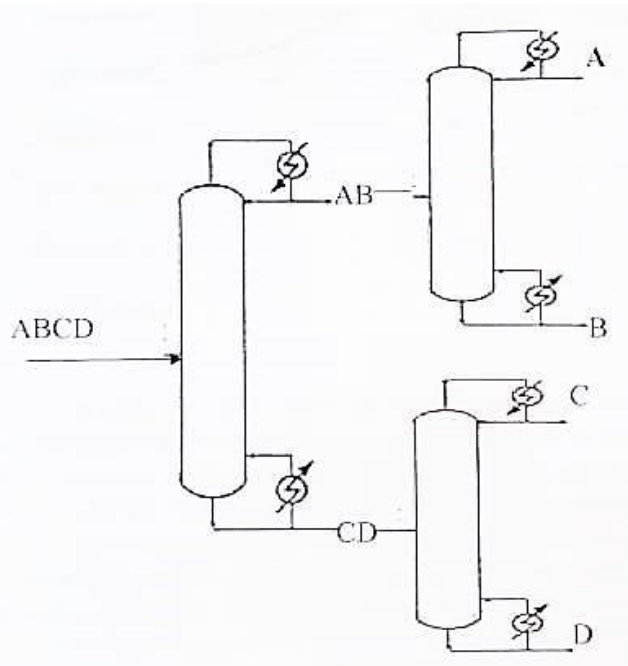

Fig.2 Optimum sequence for four-component mixture separation 
International Journal of Engineering Research and Technology. ISSN 0974-3154, Volume 13, Number 9 (2020), pp. 2305-2312

(C) International Research Publication House. https://dx.doi.org/10.37624/IJERT/13.9.2020.2305-2312

Example 2:

The problem data are shown in table studied by Heaven [28] for separation the mixture of five light hydrocarbons into pure components by ordinary distillation

Table 10. Data for example 2:

\begin{tabular}{|c|c|c|c|c|}
\hline Component & Mole fraction & $\begin{array}{c}\text { Boling point Temp } \\
(\mathrm{k})\end{array}$ & $\begin{array}{c}\text { Normal boiling Pt } \\
\text { difference }(\mathrm{k})\end{array}$ & Relative volatility $\alpha$ \\
\hline A: Propane & 0.05 & 231.1 & & 30.2 \\
\hline & & & & 2.00 \\
\hline B: I-Butane & 0.15 & 261.3 & 11.4 & 1.33 \\
\hline C: N-Butane & 0.25 & & & 2.40 \\
\hline & & 272.7 & & 1.52 \\
\hline D: I-Pentane & 0.2 & 300.8 & 8.2 & \\
\hline & & & & \\
\hline E: N-Pentane & 0.35 & 309.0 & & \\
\hline
\end{tabular}

The Summary of quantification rule is shown in the Table11:

\begin{tabular}{|c|c|c|c|c|c|c|}
\hline Split & $\begin{array}{c}\text { Boiling } \\
\text { point } \\
\text { Difference } \\
\left(\Delta \mathrm{T}_{\mathrm{B}}\right)\end{array}$ & $\begin{array}{c}\text { Relative } \\
\text { volatility } \\
(\alpha)\end{array}$ & $\begin{array}{c}\text { Estimated } \\
\text { mass load } \\
(\mathrm{EML})\end{array}$ & $\begin{array}{c}\text { Normalize } \\
\text { boiling } \\
\text { point } \\
\text { difference } \\
\left(\mu_{\mathbf{1}}\right)\end{array}$ & $\begin{array}{c}\text { Normalize } \\
\text { relative } \\
\text { volatility } \\
\left(\mu_{2}\right)\end{array}$ & $\begin{array}{c}\text { Normalize } \\
\text { Estimated } \\
\text { mass load } \\
\left(\mu_{3}\right)\end{array}$ \\
\hline $\mathrm{A} / \mathrm{BCDE}$ & 30.2 & 2 & 2.042 & 1 & 1 & 0.1832 \\
\hline $\mathrm{AB} / \mathrm{CDE}$ & 11.4 & 1.33 & 1.5 & 0.145 & 0 & 0.5 \\
\hline $\mathrm{ABC} / \mathrm{DE}$ & 28.1 & 2.40 & 1.3 & 0.904 & 1 & 0.7 \\
\hline $\mathrm{ABCD} / \mathrm{E}$ & 8.2 & 1.52 & 1.458 & 0 & 0.178 & 0.416 \\
\hline
\end{tabular}

The following table is summarized standard the calculation of standard deviation ( $\sigma$ ) by equation (7) and amount of information $\left(\mathrm{C}_{\mathrm{j}}\right)$ as shown in table 12

\begin{tabular}{|l|c|c|c|c|c|}
\hline & A/BCDE & AB/CDE & AB/CDE & AB/CDE & $\begin{array}{c}\text { Standard deviation } \\
(\sigma)\end{array}$ \\
\hline Normalize boiling point difference $\left(\mu_{1}\right)$ & 1 & 0.145 & 0.904 & 0 & 0.512718 \\
\hline Normalize relative volatility $\left(\mu_{2}\right)$ & 1 & 0 & 1 & 0.178 & 0.530962 \\
\hline Normalize Estimated mass load $(\mu 3)$ & 0.1832 & 0.5 & 0.7 & 0.416 & 0.213961 \\
\hline
\end{tabular}

The values of $R_{i k}$ are as follows: $R_{12}=0.965, R_{13}=-0.1007$ and $\quad R_{23}=-0.06577$

And then

$\mathrm{C} 1=0.582167, \mathrm{C} 2=0.584338 \quad$ and $\quad \mathrm{C} 3=0.46354$

And then

$\mathrm{W} 1=0.357148, \mathrm{~W} 2=0.35848$ and $\mathrm{W} 3=0.284373$

For obtain decision - maker, D, (or the multi-criteria-score of firm), the following table is constructed.

Table 13: Evaluation of decision maker

\begin{tabular}{|c|c|c|c|c|c|}
\hline Solutions & W1. $\mu 1$ & W2. $\mu 2$ & W3. $\mu 3$ & $\begin{array}{c}\text { multi-criteria-score } \\
\text { (D) }\end{array}$ & ranking of frim \\
\hline $\mathrm{A} / \mathrm{BCD}$ & 0.357148 & 0.35848 & 0.052097 & 0.767724 & 2 \\
\hline $\mathrm{AB} / \mathrm{CD}$ & 0.051786 & 0 & 0.142186 & 0.193973 & 3 \\
\hline $\mathrm{ABC} / \mathrm{DE}$ & 0.322861 & 0.35848 & 0.199061 & $\mathbf{0 . 8 8 0 4 0 2}$ & $\mathbf{1}$ \\
\hline $\mathrm{ABCD} / \mathrm{E}$ & 0 & 0.063809 & 0.118299 & 0.182108 & 4 \\
\hline
\end{tabular}

By comparing the values of multicriteria-score (D) for all the possible split, split ABC/D is chosen for it yield the highest D value that is 1 . 
International Journal of Engineering Research and Technology. ISSN 0974-3154, Volume 13, Number 9 (2020), pp. 2305-2312

(C) International Research Publication House. https://dx.doi.org/10.37624/IJERT/13.9.2020.2305-2312

The resulting sequence is $\mathrm{ABC} / \mathrm{D}$

Summary of results in table 14:

\begin{tabular}{|c|c|c|c|c|c|c|}
\hline split & $\Delta \mathrm{Tb}$ & $\alpha$ & EML & $\mu 1$ & $\mu 2$ & $\mu 3$ \\
\hline $\mathrm{A} / \mathrm{BC}$ & 30.2 & 2 & 0.4 & 1 & 1 & 0.6 \\
\hline $\mathrm{AB} / \mathrm{C}$ & 11.4 & 1.33 & 0.2 & 0 & 0 & 0.8 \\
\hline
\end{tabular}

Table 15 Summary of result for standard deviation

\begin{tabular}{|l|c|c|c|}
\hline & A/BC & A/BC & Standard deviation $(\sigma)$ \\
\hline Normalize boiling point difference $\left(\mu_{\mathbf{1}}\right)$ & $\mathbf{1}$ & 0 & 0.707107 \\
\hline Normalize relative volatility $\left(\mu_{\mathbf{2}}\right)$ & 1 & 0 & 0.707107 \\
\hline Normalize Estimated mass load $\left(\mu_{3}\right)$ & 0.6 & 0.8 & 0.141421 \\
\hline
\end{tabular}

$\mathrm{R} 12=1 \quad \mathrm{R} 13=-1 \quad \mathrm{R} 23=-1$

and then

$\mathrm{C} 1=1.414214, \mathrm{C} 2=1.414214$ and so $\mathrm{C} 3=0.565685$

and then

$\mathrm{W} 1=0.416667, \mathrm{~W} 2=0.416667$ and $\mathrm{W} 3=0.204817$

For obtaining decision - maker, D, (or the multi-criteria-score of firm), the following table is constructed:

Table 16: Evaluation of decision maker

\begin{tabular}{|c|c|c|c|c|c|}
\hline Solutions & W1.X1 & W2.X2 & W3.X3 & multi-criteria-score (D) & ranking of frim \\
\hline A/BC & 0.416667 & 0.416667 & 0.1 & $\mathbf{0 . 8 3 3 3 3 3}$ & $\mathbf{1}$ \\
\hline $\mathrm{AB} / \mathrm{C}$ & 0 & 0 & 0.133333 & 0.133333 & 2 \\
\hline
\end{tabular}

Comparing the values of multicriteria score (D) for all the possible split, split $\mathrm{A} / \mathrm{BC}$ is chosen for it yield the highest $\mathrm{D}$ value that is 1 .

The resulting sequence is $\mathbf{A B C} / \mathbf{D E}, \mathbf{A} / \mathbf{B C}, \mathrm{B} / \mathbf{C}$ and $\mathrm{D} / \mathbf{E}$

The total cost of possible separation sequence schemes in table 17

\begin{tabular}{|c|c|c|}
\hline NO. & Separation & Cost*106/\$/yr) $^{6}$ \\
\hline 1 & ABC/DE,D/E,A/BC,BC & 2.087 \\
\hline 2 & ABC/DE,D/E,AB/C,A/B & 2.329 \\
\hline 3 & AB/CDE,A/B,C/DE,D/E & 2.432 \\
\hline 4 & $\mathrm{AB} / \mathrm{CDE}, \mathrm{A} / \mathrm{B}, \mathrm{CD} / \mathrm{E}, \mathrm{C} / \mathrm{D}$ & 2.758 \\
\hline 5 & $\mathrm{ABCD} / \mathrm{E}, \mathrm{A} / \mathrm{BCD}, \mathrm{BC} / \mathrm{D}, \mathrm{B} / \mathrm{C}$ & 2.778 \\
\hline 6 & $\mathrm{ABCD} / \mathrm{E}, \mathrm{ABC} / \mathrm{D}, \mathrm{A} / \mathrm{BC}, \mathrm{B} / \mathrm{C}$ & 2.846 \\
\hline 7 & $\mathrm{ABCD} / \mathrm{E}, \mathrm{AB} / \mathrm{CD}, \mathrm{A} / \mathrm{B}, \mathrm{C} / \mathrm{D}$ & 2.956 \\
\hline 8 & $\mathrm{ABCD} / \mathrm{E}, \mathrm{A} / \mathrm{BCD}, \mathrm{B} / \mathrm{CD}, \mathrm{C} / \mathrm{D}$ & 3.056 \\
\hline 9 & $\mathrm{ABCD} / \mathrm{E}, \mathrm{ABC} / \mathrm{D}, \mathrm{AB} / \mathrm{C}, \mathrm{A} / \mathrm{B}$ & 3.088 \\
\hline 10 & $\mathrm{~A} / \mathrm{BCDE}, \mathrm{BC} / \mathrm{DE}, \mathrm{B} / \mathrm{C}, \mathrm{D} / \mathrm{E}$ & 5.393 \\
\hline 11 & $\mathrm{~A} / \mathrm{BCDE}, \mathrm{BCD} / \mathrm{E}, \mathrm{BC} / \mathrm{D}, \mathrm{B} / \mathrm{C}$ & 5.554 \\
\hline 12 & $\mathrm{~A} / \mathrm{BCDE}, \mathrm{B} / \mathrm{CDE}, \mathrm{CLDE}, \mathrm{D} / \mathrm{E}$ & 5.692 \\
\hline 13 & $\mathrm{~A} / \mathrm{BCDE}, \mathrm{B} / \mathrm{CDE}, \mathrm{CD} / \mathrm{E}, \mathrm{C} / \mathrm{D}$ & 5.712 \\
\hline 14 & $\mathrm{~A} / \mathrm{BCDE}, \mathrm{BCD} / \mathrm{E}, \mathrm{B} / \mathrm{CD}, \mathrm{C} / \mathrm{D}$ & 5.910 \\
\hline
\end{tabular}

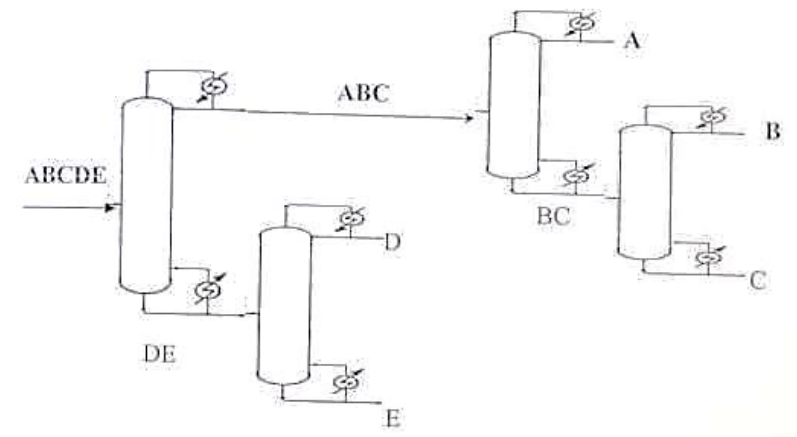

Fig.3 Optimum sequence for five-component mixture separation

The consequence of our approach is comparison with the earlier technique depending on the number of sequences developed (Nsd) and the unique search factor ( F), which is the ratio of the number of unique subproblems analyzed and the number of unique subproblems. The greater the F value, the lower efficient the search:

\begin{tabular}{|l|c|c|}
\hline \multicolumn{1}{|c|}{ Method } & $N_{s d}$ & $F(\%)$ \\
\hline HEAVEN(1969) & 14 & 100 \\
\hline RATHORE et al.(1974a,b) & 14 & 100 \\
\hline RODRIGO and SEADER(1975) & 11 & 100 \\
\hline GOMEZ and SEADER (1981) & 1 & 65 \\
\hline NATH and MOTARD(1983) & 1 & 20 \\
\hline NADGIR and LIU (1985) & 1 & 20 \\
\hline GOMEZ and SEADER (1985) & 1 & 20 \\
\hline Y.Y.RAWASH(2002) & 1 & 20 \\
\hline
\end{tabular}

Where $\mathrm{N}_{\mathrm{sd}}$ is the number of sequence developed 
International Journal of Engineering Research and Technology. ISSN 0974-3154, Volume 13, Number 9 (2020), pp. 2305-2312

(C) International Research Publication House. https://dx.doi.org/10.37624/IJERT/13.9.2020.2305-2312

\section{CONCLUSION}

Multiple criteria decision method has been suggested for synthesis sharp separation sequences by quantification of the three rules The proposed algorithm method is characterized by its simplicity and can be implemented by hand calculation when applied for problems which had been mentioned earlier in literature yielded optimum solutions which are consistent with the reported values and overcoming the barriers of using heuristic, evolutionary and mathematical programming.

\section{REFERENCE}

[1] Hendry J.E.,Rudd D.F and SeaderJ.D.,"Synthesis in the design of chemical process ",A.I.Ch.E.J.,19,PP.1.1973

[2] Hlavacek V.," Synthesis in the design of chemical processes",Comp.\&Chem.Eng.,2,pp.67,1978

[3] Westerberg A.W.,"A review of process synthesis ",in"Computer applications to chemical engineering" R.G Squires and G.V.Reklaitis(eds), ACS Symp.Series, 124,Am.Chem.soc., 1980

[4] Stephanopoulos G.,"synthesis of process flow sheet : An adventure in heuristic design or utopia of mathematical programming ",in"Foundations of computer -aided chemical process design "R.H.S.Mah and W.D.Seider(eds),Nat.Sci.Found .New-York,1981

[5] Nishida N.,Stephanopoulos G. and Westerberg A.W.,"A review of process synthesis ",A.I.CH.E.J.,27,PP.321,1981

[6] UmedaT.,"Computer-aided process synthesis",Comp.\& Chem.Eng.,7,pp.279,1983

[7] Westerberg A. W.," The synthesis of distillation-based separation systems",Comp.\&Chem.Eng.,9,pp.421,1985

[8] Floquet P.,Pibouleau L. and DomenechS.,"Mathematical programming tools for chemical engineering process design synthesis ",Chem.Eng.Process.,23,pp.99,1988

[9] Hendry J.E.and HugesR.R.,"Generating separation process flow sheets",Chem.Eng.Prog.,68,pp.71,1972

[10] Westerberg A.W. and G.Stephanopoulos (1975)," Studies in process synthesis I: Branch and bound strategy with list techniques for the synthesis of separationschemes",Chem.Eng.Sci., Vol.30,pp.963.

[11] Rodrigo B.F.R. and J.D.Seader (1975),"Synthesis of separation sequences by ordered branch search ",A.1.Ch.E. J.Vol.21,pp.885

[12] Andrecovich M.J. and Westerberg A. W., "A MILP formation for heat-integrated distillation sequence synthesis",A.I.Ch.E.J.,31,pp.1461,1985

[13] Floquet P., Pibouleau L. andDomenech S., "Agencement de colonnes de rectification complexes",Chem.Eng.J.,47,PP.119,1991

[14] NathR. And Motard R. L.," Evolutionary synthesis of separation processes", A.I.Ch.E.J.,27,PP.578,1981

[15] Lu M.D. and Motard R.L.," Computer-aided total flow sheet synthesis", Comp.\& Chem. Eng.,9,pp.43,1985

[16] Stephanopoulos G. and Westerberg A.W.," Studies in process synthesis : part II Evolutionary synthesis of optimal process flow sheet",Chem.Eng.Sci.,31,pp.195,1976
[17] Seader J.D. and Westerberg A.W.," A combined heuristic and evolutionary strategy for synthesis of simple separation sequence ", A.I.Ch.E.J.,23,PP.951,1977

[18] Heaven D.L.," Optimal sequencing of distillation columns in multicomponent fractionation ", M. S. Thesis Univ. of California, Berkeley, 1969

[19] Powers G.J.," Recognizing patterns in the synthesis of chemical processing systems ", Ph. D. Thesis, Univ. of Wiscosin, Madison, 1971

[20] Nishimura H. and Hiraizumi Y., " Optimal system pattern for multicomponent distillation systems", Int.Chem.Eng.,11,pp.188,1971

[21] Thompson R.W. and King C.J.," Systematic synthesis of separation schemes", A.I.Ch.J.,8.PP.941,1972

[22] Rudd D.F., Power G.J. and Siirola J.J., " Process synthesis ", Prentice -Hall, Englewood Cliffs, NJ,1973

[23] Niida K., Itoh J., Umeda T. and Ichikawa A., " Some expert system experiments in process engineering", I.Chem.E.Symp.Series,92,pp.529, 1985

[24] Douglas J.M., " A hierarchical decision procedure for process synthesis ", A.I.Ch.E.J.,31,PP.353,1985

[25] Lu M.D. and Motard R.L.," A strategy for the synthesis of separation sequence", I. I. Chem. Symp.Series,74,pp.141,1982

[26] Diakoulaki, D., Mavrotas, G., \& Papayannakis, L. (1995). Determining objective weights in multiple criteria problems: The critic method. Computers \& Operations Research, 22(7), 763-770

[27] Floudas C.A. and S.H.Anastasiadis (1988),"Synthesis of distillation sequenceswith several multi-compnent feed and product streams", Chem.Eng.Sci.Vol.43, pp.2407.

[28] Heaven D.L.," Optimal sequencing of distillation columns in multicomponent fractionation ", M. S. Thesis Univ. of California, Berkeley, 1969 